\title{
Contents, Vol. 5, 1995
}

Managing Editor

F. Lang, Tubingen

Editorial Board

L. Birnbaumer,

Los Angeles, Calif. M. Caplan,

New Haven, Conn. M. Cereijido, Mexico City G.H. Giebisch,

New Haven, Conn. H. Glossman, Innsbruck M. Gottesman,

Bethesda, Md. R. Greger, Freiburg S. Grinstein, Toronto H. Grunicke, Innsbruck D. Häussinger,

Freiburg E.K. HofГman, Copenhagen M. Horster, Munich R. Iyengar, New York, N.Y. R.

Kinne, Dortmund P. Lauf, Dayton, Ohio

B. Lindemann,

Homburg/Saar W.H. Moolenaar,

Amsterdam

F. Morel, Paris

H. Murer, Zurich

S. Nahorski, Leicester

E. Neher, Göttingen

B. Nilius, Leuven

H. Oberleithner, Würzburg

O.H. Petersen, Liverpool

J. Pouysségur, Nice

L. Reuss, Galveston, Tex.

E. Rozengurt, London

I. Schulz, Homburg/Saar

S.G. Schultz, Houston, Tex.

G. Schulz, Freiburg

S. Silbernagl, Würzburg E. Wright,

Los Angeles, Calif.

KAHGEK

Contents Vol. 5,1995

No.1

No. 2

Original Paper

Expression of a Protein in Rat Kidney and Distal 1

Colon That Is Related to the Gastric

H,K-ATPase

Okusa, M.D.; Gottardi, C.J.; Rajendran, V.M.; 
Binder, H.J.; Caplan, MJ.

Abnormal Function of Porcine Malignant Hyper- 10 thermia Calcium Release Channel in the Absence and Presence of Halothane Nelson, T.E.; Lin, M.

Heat-Stable Toxin from Escherichia coli Acti- 23

vates Chloride Current via cGMP-Dependent Protein Kinase Lin, M.; MacLeod, K.; Guggino, S. Isolation and Characterization of a $\beta$-Galacto- $\quad 33$

side-Binding Protein (14kD) from Rat Liver

Nuclei

Cuperlovic, M.; Jankovic, M.; Pfeifer, K.;

Müller, W.E.G.

Cellular Damage in the Rat Heart Caused by the 45 Artificial Generation of Oxygen Radicals

Daniels, S.; Duncan, C.J.

Announcement $\quad 59$

Abstracts

2nd Sectoral Meeting on in vitro Evaluation of the Toxicity and Pharmacological Activity of

Molecules Innsbruck/Igls, April 5-8, 1994 Guest Editor: Walter Pfaller, Innsbruck

Foreword 60

Pfaller, W.

Original Paper

Pharmacological Evidence that Gold-Protein-

Substance P Complex Activates Neurokinin NKi

Receptors

Cathieni, M.M.; Mastrangelo, D.; Taban, C.H.

Adenine and Pyridine Nucleotides in Erythroid 96

Cell Development

Ninfali, P.; Baronciani, L.; Sani, F.

Antiserum against Proteins of the Na+, K+,2C1- 107 Cotransporter in Ehrlich Ascites Tumor

Cells Inhibits Volume Regulation and Bumetanide-Sensitive K+ Influx Bækgaard, A.; Jensen, B.S.; Hoffmann, E.K.

Dopamine Activates Apical Membrane Cl 118

Conductance and Inhibits Fluid Absorption in Amphibian Gallbladder by Elevating Intracellu-lar cAMP Subramanyam, M.; Altenberg, G.A.; Reuss, L.

Regulation of Expression of Surface Aminopepti- 127 dase N in Human Glomerular Mesangial Cells. II. Effect of Cyclic Nucleotides, Growth Factors and Mitogens Stefanovic, V.; Vlahovic, P.

Cellular Damage in Mouse Skeletal Muscle 135

Caused by Menadione McCall, K.E.; Duncan, C.J.

II

No. 3

Original Paper

Epidermal Growth Factor, Platelet-Derived 145

Growth Factor AB, Insulin, Lysophosphatidic Acid, and Serum Modulate K+ Channel Properties in Chicken Embryo Fibroblasts Repp, H.; Matzek, A.; Draheim, H.; Malettke, N.; Dreyer, F.

Effect of Verapamil on Endothelin-1 -Induced 155

Proliferation in Cultured Rat Mesangial Cells Montero, A.; Rodríguez-López, A.M.; Carretero, J.; González-Sarmiento, R.; Rodríguez-Barbero, A.; López-Novoa, J.M. 
Characterization of Human Placental 167

11 ß-Hydroxysteroid Dehydrogenase, a Key Enzyme of Corticosteroid Metabolism Blum, S.; Bühler, $\mathrm{H}$.

L-Arginine Supplementation Antagonizes the 176

Effects of Angiotensin II and Endothelin 1 on Mesangial Cell Proliferation Mattana, J.; Singhal, P.C.

Activation of the Membrane Complex That 193

Causes Release of Creatine Kinase in Mammalian Skeletal Muscle McCall, K.E.; Duncan, C.J.

No. 4

Editorial

A Tribute to Eberhard Frömter Korbmacher, C; Kottra, G.; Lang, F.

203

Original Paper

A Chromanol Type of K+ Channel Blocker Inhib- 204 its Forskolin- but Not CarbacholMediated Cl" Secretion in Rat and Rabbit Colon Ecke, D.; Bleich, M.; Lohrmann, E.; Hropot, M.; Englert, H.C.; Lang, H.J.; Warth, R.; Rohm, W.; Schwartz, B.; Fraser, G.; Greger, R.

Protein Kinase Inhibitor H7 Prevents the 211

Decrease of Tight Junction Resistance Induced by Serosal Ca2+ Removal in Necturus

Gallbladder Epithelium Kottra, G

Glibenclamide Inhibits an Outwardly Rectifying 222 Chloride Channel in M-1 Mouse Cortical Collecting Duct Cells Volk, T.; Rabe, A.; Korbmacher, C.

A Ca2+-Activated 23-pS K+ Channel in a Human 232 Submandibular Gland Duct Cell Line (HSG) Ishikawa, T.; Cook, D.I.

Osmotic Sensitivity of the Hyperpolarization- 243 Activated Cl Current in Mouse Mandibular Duct Cells Komwatana, P.; Dinudom, A.; Young, J.A.; Cook, D.I.

Inhibition of Rat Hepatocyte K+ Conductance by 252

Serotonin

Apfel, H.; Wagner, C.A.; Schmitt, M.; Waldegger, S.;

Häussinger, D.; Lang, F.

Characterization of Cytosolic Cl" Channel Inhibi- 259 tors by Size Exclusion Chromatography Krick, W.; Disser, J.; Rabe, A.; Frömter, E.; Hansen, C.P.; Roch, B,; Kunzelmann, K.; Greger, R.; Fehlhaber, H.-W.; Burckhardt, G.

HOE 694 Blocks Na+/H+ Exchange in Human B 269 Lymphoblasts without Influencing

Proliferation Rosskopf, D.; Scholz, W.; Lang, H.J.; Schölkens, B.A.; Siffert, W.

Expression and Activity of the $\mathrm{Na}+/ \mathrm{H}+$ Exchanger $276 \mathrm{NHE}-1$ in Various Tissues of

Spontaneously Hypertensive Rats and Normotensive Wistar-Kyoto Rats Rosskopf, D.; Haider,

N.; Quednau, B.; Siffert, W.

Stable Measurements of Intracellular Calcium 286 Concentrations with Fura-2 in Isolated Rabbit

Renal Proximal Tubules Yamada, H.; Seki, G; Taniguchi, S.; Uwatoko, S.; Suzuki, K.;

Kurokawa, K.

Morphine Analogues: Relationship between 289 
Chemical Structure and Interaction with Proximal Tubular Transporters - Contraluminal Organic Cation and Anion Transporter, Luminal H+/Organic Cation Exchanger, and Luminal Choline Transporter Ullrich, K.J.; Rumrich, G.

Ill

No. 5

No. 6

Original Paper

Original Paper

Glucose Decreases Intracellular Free Calcium 299 and pH in Cultured Rat Aortic Vascular Smooth Muscle Cells: Role of Ca2+-ATPase Wang, X.; Lien, Y.-H.H.; Gillies, R.J.; MartínezZaguilán, R.

Involvement of Protein Kinase C in Activation 313 of Drosophilafos and hsp 70 Engel, M.;

Cornelius, G.

Effects of Sex Hormones on Cyclic Nucleotide 318 Metabolism in Cultured Bovine Aortic Endo-thelial Cells Ahmad, S.S.; Stewart, GJ.

Dual Activation of the Damage System that 330

Causes the Release of Cytosolic Proteins in the Perfused Rat Heart Daniels, S.; Duncan, C.J.

A New Preparation of Pancreatic Ducts for 344

Patch-Clamp Studies Novak, I.; Hug, M.J.

353

Culture of Human Kidney Proximal Tubular

Cells - The Effect of Various Detachment

Procedures on Viability and Degree of Cell

Detachment

Jung, K.; Hampel, G; Scholz, M.; Henke, W.

Cytoskeletal Regulation of hCG-Induced Recep- 361 tor Clustering in Transformed Leydig Cells

Maurer, D.R.; Wimalasena, J.; Indrapichate, K.; Puett, D.; Majercik, M.H.

Differential Effects of Endoplasmic Reticulum 371 Ca2+-ATPase Inhibitors on Madin-Darby

Canine Kidney Cells Lien, Y.-H. H.; Wang, X.; Martínez-Zaguilán, R.

In vitro Effects of Oxytocin and Vasopressin on 380 Cyclic Nucleotide Production by Bovine Granu-losa Cells Sirotkin, A.V.

Effects of Benzamil in Human Cystic Fibrosis 385

Airway Epithelium

Blank, U.; Clauss, W.; Weber, W.-M.

$\mathrm{Li}+/ \mathrm{Na}+$ Exchange in Trout Erythrocytes 391

Borggreven, J.M.P.M.; Gorissen, R.; van Norren, K.; de Pont, J.J.H.H.M.

Effects of Adriamycin on the Balance of Glomer- 399 ular Protein Metabolism: Studies in

Isolated Glo-meruli of the Atlantic Hagfish, Myxine glutinosa Kastner, S.; Fels, L.M.; Koob-

Emunds, L.; Piippo, S.; Stolte, H.

398408410412

Erratum

Author Index Vol. 5 Subject Index Vol. 5 Acknowledgements to Referees

S. Karger 
Medical and Scientific Publishers Basel $\cdot$ Freiburg $\cdot$ Paris $\cdot$ London New York $\cdot$ New Delhi · Bangkok Singapore $\cdot$ Tokyo $\cdot$ Sydney

Drug Dosage

The authors and the publisher have exerted every effort to ensure that drug selection and dosage set forth in this text are in accord with current recommendations and practice at the time of publication. However, in view of ongoing research, changes in government regulations, and the constant flow of information relating to drug therapy and drug reactions, the reader is urged to check the package insert for each drug for any change in indications and dosage and for added warnings and precautions. This is particularly important when the recommended agent is a new and/or infrequently employed drug.

All rights reserved.

No part of this publication may be translated into other languages, reproduced or utilized in any form or by any means, electronic or mechanical, including photocopying, recording, microcopying, or by any information storage and retrieval system, without permission in writing from the publisher or, in the case of photocopying, direct payment of a specified fee to the Copyright Clearance Center (see 'Information for Readers and Subscribers').

(C) Copyright 1995 by S. Karger AG, P.O. Box, CH-4009 Basel (Switzerland) Printed in Switzerland on acid-free paper by Thür AG Offsetdruck, Pratteln

IV 